\title{
Chinese Outward FDI as a Stimulus to Research in International Business
}

\section{Jeremy Clegg ${ }^{1}$ (D) Hinrich $\operatorname{Voss}^{1}$}

Published online: 11 January 2018

(C) Springer-Verlag GmbH Germany, part of Springer Nature 2018

Within the field of study of international business (IB) theoretical development typically proceeds through the fine-tuning and adjustment of existing theory, falling short of original and fresh theorisation around a novel phenomenon. As a result, our theory building overlooks challenging and significant events, which would take us closer to a deeper understanding of real-world phenomena (Delios 2017; Buckley et al. 2017b). Chinese outward foreign direct investment (OFDI) is just such a novel phenomenon and an opportunity for the development of theory, not just to explain what is new, but to better explain what we think we already know. Within IB we are continually at risk of neglecting things that cannot be explained, simply because the preoccupation of scientific research is to seek what can be explained. As a general rule, a new phenomenon can be explained passably enough through an existing theoretical lens, with some measure of adjustment (Buckley 2017). While this adds to the weight of empirical research, it extends-but does not challenge-existing theory. When a phenomenon is truly new, existing theory may well not be the most appropriate way of investigating it. And while the extension of existing theory might be sufficient for academic publication, it fails to add to theoretical understanding and to deepen our ability to explain phenomena with the greatest generality. A consequence of this is ever decreasing usefulness for managers and policy makers (Delios 2017).

The validity of this criticism of theoretical innovation within the domain of IB is clear. For example, the Triple-L framework (Mathews 2002) was an attempt to look afresh at the phenomenon of OFDI from developing economies, especially by emerging market multinational enterprises (EMNEs), using new and more

Hinrich Voss

hv@lubs.leeds.ac.uk

L. Jeremy Clegg

ljc@lubs.leeds.ac.uk

$1 \quad$ Leeds University Business School, University of Leeds, Leeds LS2 9JT, UK 
appropriate theorisation. Emerging market firms have linkages with foreign firms, from whom they learn, and then leverage what they have learnt to become MNEs themselves. Although fresh and commendable, this approach is more of a description rather than an explanation. Indeed, it can be better-but far from completely-explained using known theories of knowledge transfer, knowledge diffusion, positive spillovers from inbound advanced economy FDI, coupled with innocent and strategic behaviour on the part of EMNEs both to learn, to innovate around and to exploit new knowledge (Narula 2006, 2012). The context of Chinese OFDI into the European Union (EU) represents the ideal nursery for theory. It epitomises the inversion in FDI flows that is underway in the world economy, as emerging economies such as China spawn a growing cohort of firms internationalising via FDI.

Why should an enquiry into Chinese OFDI in the EU be able to tell us something important that we did not know before? The EU focus of this Focused Issue brings together another strand of special conditions that test existing theory. The field of research of international business needs a new approach to EMNEs, to use these firms' behaviour to challenge the standard model of IB theory, rather than endeavouring to substantiate the status quo, and demonstrate that known theory still works-not least because existing theory already does not enjoy universal applicability. In what ways the standard theoretical model does not work remains a potent question. The answer will have implications not only for EMNEs, but for all multinationals, and for the standard model itself, which must be capable of explaining multinational behaviour from emerging and advanced economies alike (see for example, Luo and Tung 2017). In what follows we illustrate some of the tensions that have arisen in IB theory because of the emergence of EMNEs and OFDI from developing countries, and that underline why Chinese OFDI in the EU is today such a fruitful research ground and an ideal context for theory development.

Chinese firms which enter advanced economies like the EU may face backlashes of various types. First, there may be resentment by domestic industry similar to that experienced by US firms in Europe in the 1950s and 1960s and by Japanese investors in the 1980s (Mason 1994; Pokarier 2004; Vernon 1971). Domestic firms eye the new, unknown, entrants with caution and suspect them of being unfairly supported by their home government. But second, and potentially more important for the development of EMNEs, firms entering under some measure of encouragement by home government action may be inadequately prepared for competition, both within the developing economies, but also for further internationalisation in other economies. The government-led internationalisation process may result in firms that do not comprehend the necessity of learning about their host country environment, and therefore do not develop the necessary capabilities for operation within competitive markets. Although international, a consequence is that these firms are only able to survive in host markets and industry sectors in which their home government is able to offer them support. And, if that support is withdrawn, then these firms would inevitably struggle.

Instances of this suggest that the internationalisation success of EMNEs may be especially variable, and particularly liable to falter where their initial investments took place in markets in which they had enjoyed home country patronage. This can 
be seen as a special case of the more general situation of investment preferentially directed towards markets that are more familiar, building upon the concept of psychic distance (Johanson and Vahlne 1977), but further generalised to conceptual variables beyond that of culture alone, such as institutional and technological distance (Ghemawat 2001). At the firm level, it could also be predicted that firms which have internationalised into protected environments might develop overconfidence in their abilities to internationalise into all foreign market environments (Buckley et al. 2016). Such hubris would result in riskier subsequent investments than would otherwise apply to firms that had internationalised on the basis of their intrinsic competitive abilities.

Chinese firms that have over-relied on internationalising on the back of Chinese government encouragement live within a "bubble", and may be overconfident in their outward investment, both within protected environments and in other environments (Buckley et al. 2016). This overconfidence should be detectable in higher failure rates, below expected performance in general, and idiosyncratic investment choices. While this reasoning has been set out for the case of developing economies as hosts of Chinese investment, the general case that Chinese outward investment receives protection is worth consideration theoretically and empirically, as it is unlikely that policies will be applied only to one set of countries. The degree, or nature, of any such protection may be different, but the effect should nevertheless remain. The important point here is that, in this, China is far from being an exception, but rather is a particularly instructive example of the more general situation.

Within mainstream IB research the action of state capitalism is neither well integrated nor well analysed. Studying emerging economy OFDI, of which Chinese OFDI is a prime example, allows us to recognise what has always been there-that there exists a universal relationship between government and enterprises, that is, home governments and their home-grown enterprises (Hillman and Keim 1995; Hocking and McGuire 2002). The prominence of state capitalism in Chinese and emerging economies' OFDI helps us to avoid becoming blinded to the ubiquity of the often close relationship between businesses and their home governments. In this way Chinese investment abroad liberates us to challenge existing theory. The occurrence of state capitalism in Chinese OFDI enables us to begin the theorisation process of why and how governments become involved in directing the activities of their enterprises in the international domain. The Chinese experience provokes us to challenge, rather than to extend, existing theory that remains silent on important anomalies that are conventionally and collectively overlooked by academic research. The influence of Chinese state capitalism is visible in Europe in the form of a bandwagon effect between private and state-owned Chinese firms (De Beule et al. 2017). Indications of a 'coordinated' or 'orchestrated' OFDI approach between Chinese private and state investors, and the Chinese government itself, raise questions about the long-term benefits of OFDI to the investor, as argued above, and surely also to the host economies. This research also challenges our application of internalisation theory. Such overseas investments may not be motivated to internalise imperfect external markets simply to achieve greater organisational and productive efficiency abroad within a specific business context, 
but rather to more effectively benefit the wider home economy, and possibly to exert political power. This 'coordinated approach' also calls into question how Chinese firms experience and respond to institutional distance, and their ability to deviate in their behaviour from host country norms-or indeed to change them (Fortwengel 2017).

The "Go Global" agenda introduced to promote Chinese OFDI abroad (Buckley et al. 2017a, 2018) is an intrinsic part of state capitalism within China. Following the announcement of the Go Global strategy, regional forums were established in Central and Eastern Europe, and elsewhere, to foster new international economic relationships with China, and to encourage Chinese firms to identify overseas partners in these economies. Chinese state owned enterprises (SOEs) have internationalised with a clear state agenda behind them. The question for research that arises from this is whether the Chinese firms that internationalise are actually able to benefit from this agenda, and whether these firms elicit positive feelings (building on this benefit) from the host countries in which they invest (Holtbruegge and Berning 2018). It might be argued that SOEs could be more effective at creating positive local impact than privately owned enterprises. According to welfare economics and the arguments for state intervention, SOEs should be better suited to addressing market failures, not only within the home economy but, by extension of theory, also within host economies. This perception may be shared within home and host economies alike when cordial relations already exist between the two economies. SOEs may even be credited with generating greater positive spillovers within the host economy if they are fulfilling a perceived investment gap that other foreign investors have ignored. In this case, the business model of SOEs will appear to be more effective in creating social value than any alternatives. While the foreign SOE might conceivably benefit the host economy on account of its inherent focus on correcting such perceived market failures, the extent to which the investor itself is benefiting from the productivity of the investment is worthy of investigation. Some evidence exists with which to question the performance of Chinese OFDI, suggesting overpayment in acquisitions coupled with lack of clarity in strategic focus. On this basis, Holtbruegge and Berning (2018) conjecture that when Chinese investments in Europe seem to perform well, it is ultimately because of Chinese home government support. This involves assisting Chinese firms in pursuing market entry strategies that otherwise would be beyond their reach.

The application of the standard model of international business theory, based on the concept of ownership or firm-specific advantage (Dunning and Lundan 2009; Rugman 1981), to emerging market OFDI and to Chinese OFDI in particular, does us the service of enabling anomalies - such as how to explain the idiosyncrasies of Chinese firms' FDI performance-to accumulate to the point where we cannot ignore them anymore. Within this standard model, Hensmans and Liu (2018) have considered how the type of relationship between European affiliates and their Chinese headquarters influences the knowledge performance of Chinese MNEs. Their focus on the internal barriers within the Chinese MNE is of great potential value for understanding the root cause of performance differences between Chinese MNEs within the EU. Chinese firms may exhibit greater variation in this regard, and thus offer a unique laboratory for scientific enquiry. While Hensmans and Liu 
(2018) demonstrate why we should continue to use the "standard model" in estimating empirical relationships in the real world, nevertheless, as the anomalies accumulate we must seek to explain them. Ultimately, this may involve not simply bolting on corrections to the standard model, but revising, or even rejecting, it.

A further respect in which the EU focus of this Focused Issue brings together special conditions that confront existing theory and thinking springs from the Union's distinct character as an area undergoing regional integration. On paper, the EU is often portrayed as a single market. In reality, and for foreign investors from the emerging economies in particular, it may appear to be far from a single market (Egan and Guimarães 2017). Put simply, it is not "Europe and China"; it is "Europe and China and the member states of the European Union and China" simultaneously - on account of the large degree of variation across member states in relevant laws, attitudes, and politics. This heterogeneity within the EU itself challenges our conceptualisation of host economies. Economically, institutionally, culturally, each of the EU member states is different. This variation helps us to tease out the differences between member states and Chinese investors, and to investigate the more micro level relationships that, only once aggregated, appear as the "EU-China relationship". This makes the EU the ideal testbed for Chinese OFDI into the advanced economies of the world. It can also serve as a testbed for understanding how domestic institutions and firms are responding to inward investment and to the challenges that these create for the foreign investor. Firms in the EU are a popular acquisition target for East and Southeast Asian firms in general-however, the investment patterns and target responses to acquisitions are far from uniform, as shown by Alkire and Meschi (2017) and Shen and Puig (2018).

This prompts the very salient question, given projections for the growth of Chinese global OFDI stock to reach USD\$18 trillion by 2020 (Hanemann and Huotari 2015), of whether the current positive official EU policy stance towards inward FDI would remain, should the stock of Chinese FDI into the EU increase by an order of magnitude. The USA is by far the dominant investing nation in the European Union (Clegg and Voss 2012), but unlike American investment in the EU, such a magnitude (or the trajectory towards it) on the part of Chinese investors might provoke an unfavourable response from the EU, or from those individual member states that have witnessed exceptionally high inflows of Chinese investments. Shen and Puig (2018) find that in Germany-the EU member state that has pushed for stricter control of Chinese investments (Chazan 2017) - Chinese companies are consciously selecting investment locations and entry modes to reduce the risk of provoking the erection of barriers in response to the perception of threat from Chinese firms. The authors' finding nevertheless remains in line with the present official EU ambition for inward FDI from China to shake up the European economy and make it more competitive as part of the EU's Growth Agenda. As a whole, the European economy is developed and mature enough to be capable of benefiting from the pro-competitive effect of such inward FDI without being colonised by inward FDI from any one nation. However, the economies of individual member states within the EU remain highly heterogeneous. This extends to their ability to absorb and benefit from inward FDI, but also to the public tolerance of foreign interests. 
The question is if, and when, Chinese investments within the EU have achieved large scale, with ownership control residing in China, will these investments confer a commensurately great beneficial effect on host industry and the host economy? This might be achievable on account of the home government's strong desire (and sustained support) for investments to succeed. Equally, however there may arise conflicts with individual host country governments, which would have the additional dimension of impacting on the functioning of the single market across the entire EU. A further layer of uncertainty, which remains beyond the scope of this Focused Issue, is over the future nature of the relationship between the EU and China as governed by the projected comprehensive EU-China Investment Agreement (Clegg and Voss 2016). Such an agreement will cover both investment protection and market access for Chinese and for European firms in the EU and China, respectively. European economies outside of the EU, such as the United Kingdom following its withdrawal, will have to negotiate their own independent investment agreements, which almost certainly will not have the same terms as the EU-China agreement. Investment agreements and closer governmental cooperation are means of reducing the perceived risk inherent in international investments, and will form an important part of the armoury of investment promotion in the future. This is especially pertinent in the light of the attitude of Chinese investors towards risk, which has been found to be mixed, and is probably complex. While Buckley et al. (2017a) inferred that Chinese investors are risk-takers, more recent work suggests a more nuanced picture (Buckley et al. 2017a). The argument for complexity is supported by Han et al. (2017) who investigate how Chinese firms conceive of risks in the EU and Africa and how they translate this into their strategies. They find that Chinese investors are very sensitive to sources of risk and that these impact their development potential in host countries. If so, it would suggest that the way the EU and its member states handle inward Chinese FDI will be critical not only for each member state, but for the entire EU and the single market.

The above arguments, and the perspective of this Focused Issue, suggest that we may even observe mimetic behaviour within the European host economy arising from inward FDI from China. This is a contentious point, and a reversal of the normal proposition that FDI from emerging economies into the advanced economies will succumb to isomorphic pressures exerted by the host economy. One parallel is the experience of the advanced economies of the EU with inward Japanese investment in the 1970s and 1980s. During this period, host economy firms began to emulate Japanese management and organisational practices. There is also the natural tendency, according to principles of social anthropology, on the part of people to imagine that they should adopt the practices of other nationalities that are found to be aspirational, or in the ascendancy (Gajewska-De Mattos et al. 2004). This applies to national corporate cultures that have enjoyed ostensible success, but it may extend more generally to the desire to emulate a wide range of practices. There is already evidence of something of a "love affair" between EU host economy governments, their inward promotion agencies and inward investment from China (Clegg and Voss 2012). This rests on some measure of belief that Chinese investors offer salvation for the slow secular growth of the European 
economy. However justified this belief, without doubt inward investment from China will form an increasing part of the strategy of the EU, its member states, and other economies of the world, to achieve improved performance. Systematic enquiry into to how best to design and pursue this strategy will be important both for the scientific research agenda in International Business, for China, and for the EU. The purpose of this Focused Issue is to contribute to this agenda.

Acknowledgements We would like to thank the editors and the reviewers for their invaluable support in producing this Focused Issue. We would like express our gratitude for funding from the European Union's Lifelong Learning Programme, under the Jean Monnet Programme: Key Activity 1, Reference: 200301-LLP-1-2011-1-UK-AJM-IC, and from the Sino-British Fellowship Trust, for our project entitled "European Integration and Chinese Foreign Direct Investment in the EU". This project supported the development of this Focused Issue.

\section{References}

Alkire, T., \& Meschi, P.-X. (2017). The decision to stay or resign following an acquisition by a Chinese or Indian company. Management International Review. https://doi.org/10.1007/s11575-017-0329-8.

Buckley, P. J. (2017). Internalisation theory and outward direct investment by emerging market multinationals. Management International Review. https://doi.org/10.1007/s11575-017-0320-4.

Buckley, P. J., Chen, L., Clegg, L. J., \& Voss, H. (2016). The role of experience in FDI location choice: Endogenous risk, exogenous risk, and high-level government visits. Journal of International Management, 22(2), 131-146.

Buckley, P. J., Chen, L., Clegg, L. J., \& Voss, H. (2017a). Risk propensity in the foreign direct investment location decision of emerging multinationals. Journal of International Business Studies. https://doi. org/10.1057/s41267-017-0126-4.

Buckley, P. J., Clegg, L. J., Voss, H., Cross, A. R., Liu, X., \& Zheng, P. (2018). A retrospective and agenda for future research on Chinese outward foreign direct investment. Journal of International Business Studies,

Buckley, P. J., Doh, J. P., \& Benischke, M. H. (2017b). Towards a renaissance in international business research? Big questions, grand challenges, and the future of IB scholarship. Journal of International Business Studies. https://doi.org/10.1057/s41267-017-0102-z.

Chazan, G. (2017). EU capitals seek stronger right of veto on Chinese takeovers. Financial Times, 14 February 2017.

Clegg, L. J., \& Voss, H. (2012). Chinese direct investments in the European Union. London: ECRAN.

Clegg, L. J., \& Voss, H. (2016). The new two-way street of Chinese direct investment in the European Union. China-EU Law Journal, 5, (1-2), 79-100.

De Beule, F., Somers, D., \& Zhang, H. (2017). Who follows whom? A location study of Chinese private and state-owned companies in the European Union. Management International Review. https://doi. org/10.1007/s 11575-017-0330-2.

Delios, A. (2017). The death and rebirth (?) of international business research. Journal of Management Studies, 54(3), 391-397.

Dunning, J. H., \& Lundan, S. (2009). Multinational enterprises and the global economy (2nd ed.). Cheltenham: Edward Elgar.

Egan, M., \& Guimarães, M. H. (2017). The single market: Trade barriers and trade remedies. Journal of Common Market Studies, 55, (2), 294-311.

Fortwengel, J. (2017). Understanding when MNCs can overcome institutional distance: A research agenda. Management International Review. https://doi.org/10.1007/s11575-017-0327-x.

Gajewska-De Mattos, H., Chapman, M., \& Clegg, L. J. (2004). Poles and Germans: An international business relationship. Human Relations, 57(8), 983-1015.

Ghemawat, P. (2001). Distance still matters. Harvard Business Review, 79(8), 137-147.

Han, X., Liu, X., Gao, L., \& Ghauri, P. (2017). Chinese multinational enterprises in Europe and Africa: How do they perceive political risk? Management International Review. https://doi.org/10.1007/ s11575-017-0331-1. 
Hanemann, T., \& Huotari, M. (2015). Chinese FDI in Europe and Germany: Preparing for a new era of Chinese capital. Berlin: Mercator Institute for China Studies and Rhodium Group.

Hensmans, M., \& Liu, G. (2018). How do the normativity of headquarters and the knowledge autonomy of subsidiaries co-evolve? Capability-upgrading processes of Chinese subsidiaries in Belgium. Management International Review. https://doi.org/10.1007/s11575-017-0333-z.

Hillman, A., \& Keim, G. (1995). International variation in the business-government interface: Institutional and organizational considerations. Academy of Management Review, 20(1), 193-214.

Hocking, B., \& McGuire, S. (2002). Government-business strategies in EU-US economic relations. Journal of Common Market Studies, 40(3), 449-470.

Holtbrügge, D., \& Berning, S. C. (2018). Market entry strategies and performance of Chinese firms in Germany: The moderating effect of home government support. Management International Review. https://doi.org/10.1007/s11575-017-0334-y.

Johanson, J., \& Vahlne, J. E. (1977). The internationalization process of the firm-a model of knowledge development and increasing foreign market commitments. Journal of International Business Studies, 8(1), 23-32.

Luo, Y., \& Tung, R. (2017). A general theory of springboard MNEs. Journal of International Business Studies. https://doi.org/10.1057/s41267-017-0114-8.

Mason, M. (1994). Elements of consensus: Europe's response to the Japanese automotive challenge. Journal of Common Market Studies, 32(4), 433-453.

Mathews, J. A. (2002). Dragon multinational: A new model for global growth. Oxford: Oxford University Press.

Narula, R. (2006). Globalization, new ecologies, new zoologies, and the purported death of the eclectic paradigm. Asia Pacific Journal of Management, 23(2), 143-151.

Narula, R. (2012). Do we need different frameworks to explain infant MNEs from developing countries? Global Strategy Journal, 2(3), 188-204.

Pokarier, C. (2004). The controversy over Japanese investment in Australia, 1987-1991: Context and lessons. Japanese Studies, 24(2), 215-231.

Rugman, A. M. (1981). Inside the multinationals. The Economics of internal markets. London: Croom Helm.

Shen, Z., \& Puig, F. (2018). Spatial dependence of the FDI entry mode decision: Empirical evidence from emerging market enterprises. Management International Review. https://doi.org/10.1007/s11575017-0332-0.

Vernon, R. (1971). Sovereignty at bay: The multinational spread of U.S. enterprises. New York: Basic Books. 